\title{
PENGARUH KINERJA MENGAJAR GURU, KETERLIBATAN ORANG TUA, AKTUALISASI DIRI DAN MOTIVASI BERPRESTASI TERHADAP PRESTASI
}

\author{
Dwi Junianto \\ SMA Negeri Tepus Gunungkidul \\ dwi_junianto05@yahoo.co.id \\ Wagiran \\ Universitas Negeri Yogyakarta \\ maswagiran@yahoo.com
}

\begin{abstract}
Abstrak
Penelitian ini bertujuan mengetahui pengaruh kinerja mengajar guru, keterlibatan orang tua, aktualisasi diri dan motivasi berprestasi terhadap prestasi siswa kelas XII pada mata pelajaran teori Teknik Kendaraan Ringan di SMK Negeri Se-Kabupaten Gunungkidul. Penelitian ini merupakan jenis penelitian kuantitatif dengan rancangan ex post facto. Populasi penelitian ini sebanyak 535 siswa dengan sampel sebanyak 237 siswa, yang ditentukan secara proportional random sampling. Teknik pengumpulan data menggunakan dua cara yaitu angket dan tes prestasi. Data penelitian yang terkumpul dianalisis menggunakan analisis regresi. Hasil penelitian menunjukkan bahwa terdapat pengaruh kinerja mengajar guru, keterlibatan orang tua, aktualisasi diri dan motivasi berprestasi masing-masing sebesar 0,145; 0,128; 0,108; dan 0,098.
\end{abstract}

Kata kunci: kinerja mengajar guru, keterlibatan orang tua, aktualisasi diri, motivasi berprestasi, prestasi belajar

\section{THE INFLUENCE OF TEACHERS' TEACHING PERFORMANCE, PARENTS' INVOLVEMENT, SELF-ACTUALIZATION, AND ACHIEVEMENT MOTIVATION TOWARD ACHIEVEMENT}

\begin{abstract}
The purpose of this study is to determine the influence level of teachers' teaching performance, parents' involvement, self-actualization and achievement motivation for the twelfth grade students' achievement on theory subject of Light Vehicle Technology of SMK Negeri in Gunungkidul Regency. This research is quantitative research which uses expost facto design. Population in this research as much as 535 students, with 237 students as respondents specified by proportional random sampling. In getting data, the writer used two techniques; questionnaires and achievement tests. The research data were analyzed using regression analysis. The results of this study show there is influence of the teachers' teaching performance, parents' involvement, self-actualization and achievement motivation each 0.145; 0.128; 0.108; and 0.098.
\end{abstract}

Keywords: teachers' teaching performance, parents' involvement, self-actualization, achievement motivation, learning achievement 


\section{PENDAHULUAN}

Penilaian merupakan istilah umum yang mencakup semua metode yang digunakan untuk menilai prestasi (performance) siswa secara individu atau sekelompok siswa (Black, 1998: 5). Berdasarkan pendapat Black di atas, penilaian dapat dilakukan dengan berbagai cara, diantaranya adalah wawancara, observasi, unjuk kerja, tes prestasi, dan lainlain.

Penilaian pembelajaran dapat dilaksanakan oleh guru, sekolah dan pemerintah. Guru melakukan penilaian dalam bentuk ulangan harian yang dilaksanakan setelah guru mengajarkan kompetensi tertentu, sekolah melaksanakan penilaian secara periodik pada akhir semester dan pemerintah melakukan penilaian pada akhir tingkat pendidikan. Penilain yang dilakukan pemerintah pada akhir satuan pendidikan dikenal sebagai Ujian Nasional. Hasil Ujian Nasional kompetensi kejuruan pogram keahlian Teknik Kendaraan Ringan pada tahun ajaran 20112012 dibandingkan pada tahun ajaran 20102011 SMK di Kabupaten Gunungkidul mengalami penurunan. Pada tahun ajaran 20102011 nilai rata-rata ujian kompetensi kejuruan pogram keahlian Teknik Kendaraan Ringan 8,53 dan pada tahun 2011-2012 nilai rata-rata ujian kompetensi kejuruan turun menjadi 7,79 , sehingga mengalami penurunan sebesar 0,73 . Jika hal ini tidak diatasi, akan berdampak pada penerimaan DU/DI pada lulusan SMK jurusan Teknik Kendaraan Ringan, karena nilai kompetensi keahlian yang baik merupakan salah satu syarat mutlak bagi siswa untuk mengisi lowongan pekerjaan yang ditawarkan.

Ngalim Purwanto (2006: 107) menyatakan bahwa faktor yang mempengaruhi prestasi belajar terbagi dalam dua kelompok yaitu: (1) faktor internal meliputi fisiologi dan psikologi. Faktor fisiologi berupa kondisi fisik dan panca indera sedangkan faktor psikologi berupa bakat, minat, kecerdasan, motivasi dan kemampuan kognitif; (2) faktor eksternal meliputi lingkungan dan instrumental. Faktor lingkungan berupa lingkungan alam dan sosial sedangkan faktor instrumental berupa kurikulum/bahan ajar, guru, sarana dan fasilitas serta adminisrasi/manajemen. Penelitian yang dilakukan oleh Kusuma Dewi, Made Yudana \& Nyoman Dantes (2013: 10) menemukan faktor internal yang berpengaruh signifikan terhadap prestasi belajar adalah minat, kreatifitas dan persepsi. Middleton \& Spanias (1999: 79) mememukan bahwa yang persepsi akan kesuksesan belajar berpengaruh terhadap prestasi. Mushtaq \& Khan (2012: 22), menemukan faktor eksternal yang berpengaruh pada prestasi belajar adalah fasilitas belajar, bimbingan guru dan orang tua. Farooq, Chaudhry, Shafiq, et al. (2011: 10), Conway \& Houtenville (2008: 451) menemukan bahwa kondisi sosial ekonomi keluarga, tingkat pendidikan orang tua dan pekerjaan orang tua berpengaruh signifikan terhadap prestasi belajar. Konstantopoulos (2006: 2578) menemukan guru dan kondisi sekolah berpengaruh signifikan terhadap prestasi belajar.

Berdasarkan hasil diskusi dengan Ketua Jurusan pada forum MGMP Teknik Kendaraan Ringan Kabupaten Gunungkidul, terdapat beberapa hal yang diduga mempengaruhi penurunan prestasi siswa. Dipandang dari faktor internal siswa, yaitu keinginan/motivasi menguasai kompetensi cukup rendah. Faktor eksternal yang dipandang sangat perpengaruh adalah guru, alat praktek, dan orang tua. Salah satu contohnya, rata-rata guru produktif mempunyai beban mengajar lebih dari 30 jam, sehingga berpengaruh terhadap kesiapan guru mengajar dan membimbing siswa.

Tugas guru dalam pembelajaran praktek adalah sebagai pembimbing, mengarahkan dan memberi contoh. Tugas ini akan semakin berat jika dalam pelaksanaan pembelajaran praktek tidak dilakukan secara team teaching dan jumlah alat alat praktek yang tidak memadai, jika dibandingkan antara jumlah siswa dan ketersediaan alat.

Latar belakang orang tua siswa SMK di Kabupaten Gunungkidul, mayoritas (> 85\%) bermata pencaharian sebagai petani. Mereka memiliki waktu bekerja dari pagi sampai sore berada di sawah/ladang, sehingga intensitas bertemu dengan anak lebih besar terjadi pada malam hari.

Faktor-faktor yang mempengaruhi prestasi belajar tersebut, perlu dikaji lebih mendalam, untuk mengetahui faktor dominan yang mempengaruhi prestasi belajar. Sehingga dengan diketahui faktor dominan yang mempengaruhi prestasi belajar, stake holder sekolah dapat mentukan strategi yang paling baik, untuk mengatasi masalah penurunan prestasi belajar siswa. 


\section{Kinerja Mengajar}

Nayyar (Khan, Shah, Khan, et al., 2012: 23) menyatakan kinerja merupakan kemampuan seseorang dalam melakukan pekerjaan tertentu, dinilai berdasarkan standar yang telah ditetapkan. Mengajar menurut DeQuely \& Gazali (Slameto, 1991: 31) berarti menanamkan pengetahuan pada seseorang dengan cara paling singkat dan tepat. Leighbody \& Kidd (1966: 2) menyatakan mengajar adalah membantu orang lain untuk belajar. Berdasarkan pengertian kinerja dan mengajar, kinerja mengajar dapat diartikan sebagai kemampuan guru dalam melaksanakan tugas/aktivitas mengajar agar siswa dapat mudah belajar.

\section{Dimensi Kinerja Mengajar}

Dalam proses belajar mengajar ada empat hal yang harus dilakukan oleh guru yaitu planning, assesment, evaluation dan monitoring (Briggs \& Sommefeldt, 2002: 93). Kyriacou (2009: 8) menyatakan tentang framework of effective teaching yaitu: (1) contex variables berdasarkan pada semua karakterisktik dalam ruang lingkup pembelajaran; (2) process variables yang berdasarkan pada apa yang terjadi di dalam kelas; dan (3) product variables merupakan dampak dari pembelajaran yang telah dipersiapkan oleh guru dan dapat digunakan sebagai penilaian. Berdasarkan ketiga hal yang disampaikan Kyriacou, disimpulkan bahwa kerangka kerja guru yang efektif adalah perencanaan, pelaksanaan dan penilaian pembelajaran. Oleh karena itu, dimensi kinerja mengajar guru paling tidak terdiri dari tiga hal, yaitu perencanaan, pelaksanaan dan penilaian pembelajaran.

\section{1) Perencanaan Pembelajaran}

Uzer Usman (2013: 61) menyatakan bahwa unsur perencanaan pembelajaran meliputi: (1) tujuan pembelajaran, (2) materi pembelajaran, (3) kegiatan pembelajaran, dan (4) alat penilaian proses. Marzano (2007: 182183) menyatakan, ketika guru merencanakan pembelajaran hendaknya memperhatikan empat hal yaitu: (1) Rules and procedures, (2) Communicating learning goals, (3) Tracking student progress on learning goals, dan (4) Celebrating success on learning goals. Setelah itu guru harus menentukan: (1) criticalinput experience, (2) activity that help them practice or deepen their knowledge, dan (3) testing task or asked to work, sehingga dapat disimpulkan, perencaaan pembelajaran yang baik meliputi: (1) guru menentukan prasarat materi yang akan disampaikan, menentukan aturan dalam pembelajaran, menyampaikan tujuan pembelajaran, merencanakan kegiatan pembelajaran; (2) perencanaan pelaksanaan pembelajaran meliputi membangun hubungan yang positif dengan siswa, bersemangat mencapai harapan yang diinginkan, dan (3) perencanaan menilai pembelajaran bertujuan mencari kemajuan belajar siswa berdasarkan pada tujuan belajar, dan pelaksanaan tes atau penugasan.

2) Pelaksanaan Pembelajaran

Guru melaksanakan pembelajaran tidak dapat terlaksana dengan baik, jika tidak mengerti prinsip-prinsip belajar, di samping menguasai materi pembelajaran (Oemar Hamalik, 2004: 33). Leighbody \& Kidd (1966: 3) menyatakan beberapa prinsip belajar yaitu: (1) kita akan belajar baik ketika kita siap untuk belajar; (2) semakin sering kita melakukan apa yang telah kita pelajari maka kita akan semakin paham; (3) apabila yang kita pelajari bermanfaat maka kita akan puas tentang apa yang kita pelajari, kita akan puas sehingga kita akan belajar lebih dan semakin ingin belajar; (4) belajar sesuatu yang baru akan lebih mudah jika berdasarkan pada apa yang telah kita pelajari; (5) belajar harus dilakukan secara bertahap; (6) belajar baik jika dilakukan dengan melakukan (learning by doing); dan (7) pembelajaran yang berhasil akan merangsang keinginan belajar yang lebih. Uzer Usman (2013: 21-31) melengkapi pendapat Leighbody \& Kidd dengan menjabarkan teknis pembelajaran yang baik, meliputi: (1) melibatkan siswa secara aktif, berupa aktivitas visual, aktivitas lisan, aktivitas mendengarkan, aktivitas gerak/praktek, dan aktivitas menulis; (2) menarik minat dan perhatian; (3) membangkitkan motivasi siswa berupa motivasi intrinsik dan ekstrinsik (kompetisi, penilaian, tujuan yang jelas); (4) prinsip individualitas; dan (5) peragaan dalam pengajaran. Kyriacou (2009: 148) menyatakan agar pembelajaran menarik dan menyenangkan maka guru hendaknya memprioritaskan active learning, problem solving, creativity, communication, cooperation, negotiation, assessment. 
Berdasakan uraian di atas, disimpulkan dalam melaksanakan tugas guru harus: (1) memprioritaskan active learning; (2) menyampaikan permasalahan dan mendorong siswa untuk menyelesaikan permasalahan tersebut; (3) kreatif/fleksibel and responsive; (4) membangun komunikasi yang positif dengan siswa; (5) membangun sikap kerja sama antar siswa; dan (6) memperhatikan perbedaan individu.

3) Menilai Pembelajaran

Cooper \& McIntyre (1996: 1) menyatakan bahwa penilaian harus dilakukan secara accountable. Sedangkan Glickman (2002: 8) menyatakan bahwa dalam menilai, hendaknya guru melakukan diagnostic assessment. Penilaian yang accountable adalah penilaian yang berdasarkan pada kenyataan yang dilakukan oleh guru dan siswa. Sedangkan diagnostic assessment adalah penilaian yang dilakukan secara terus menerus, sampai siswa mendapatkan hasil penilaian yang diharapkan/sesuai dengan kriteria.

\section{Menilai Kinerja Mengajar Guru}

Pembelajaran yang dilakukan guru harus dapat diukur (accountable), walaupun dalam proses pengukuran tidak terdapat satu cara yang paling tepat dalam mengukur kinerja mengajar guru. Middlewood \& Cardno (2001: 3-4) menyatakan bahwa guru yang berhasil adalah guru yang sungguh-sungguh memperhatikan dalam menciptakan dan mengatur lingkungan kelas (create controlled classroom environment). Glickman (2002: 25) menyatakan bahwa ada beberapa cara mengukur (observe) kinerja mengajar guru yaitu: (1) a comprehensive framework for teaching; (2) individually tailored, open-ended questionnaires; (3) student work (student responses, understandings, and achievements; dan (4) student achievement on district and state assessments.

Berdasarkan cara mengukur kinerja mengajar yang disampaikan Glickman, secara implisit mengindikasikan tentang siapa yang menilai/mengukur kinerja mengajar guru. Mereka adalah kepala sekolah dan siswa.

\section{Keterlibatan Orang Tua}

Desforges \& Abouchaar (2003: 12); Steinberg (1996: 125) menyatakan keterlibatan orang tua dapat disimpulkan sebagai segala bentuk perhatian/kegiatan orang tua yang bertujuan untuk keberhasilan pendidikan anaknya. Guru dan orang tua memiliki keinginan yang sama, terhadap keberhasilan pembelajaran. Hornby (2000: 16-17) menemukan keinginan orang tua dan guru adalah: (1) terbuka kepada guru; (2) bekerja sama dalam kedisiplinan anak; (3) membantu/memantau pekerjaan tumah anak; (4) mengajarkan kepada anak apa yang mereka harapkan; (5) menghadiri pertemuan guru dan orang tua; dan (6) menjadi relawan di sekolah.

Grolnick, Friendly \& Bellas (Wentzel \& Wigfield, 2009: 282) menyatakan terdapat tiga tipe keterlibatan orang tua yaitu: (1) keterlibatan perilaku; (2) keterlibatan intelektual; dan (3) keterlibatan personal. Steinberg (1996: 106-108) menyatakan bahwa kondisi keluarga yang dapat berpengaruh pada prestasi yaitu:

1) Acceptance adalah perasaan dicintai, dihargai, dan didukung oleh orang tua.

2) Firmness (keteguhan) adalah tingkat konsistensi orang tua pada batas-batas perilaku anak.

3) Autonomy yang berarti menunjukkan seberapa besar toleransi orang tua dan mendorong kemandirian anak

Dari berbagai uraian di atas dapat disimpulkan bahwa keterlibatan orang tua dalam pendidikan meliputi tiga hal yaitu: (1) behavioral involvement berupa membentukan kondisi keluarga yang baik (acceptance, autonomy dan firmness) dengan cara membuat peraturan bersama tentang belajar, tidur malam, menonton TV dan lain-lain, berbagi peran dalam keluarga; (2) Intelectual involvement meliputi: menstimulasi kecerdasan anak dengan membelikan buku yang diperlukan, membantu pekerjaan rumah/tugas anak, memantau akademik anak, memberi contoh dalam belajar, mendorong kebiasaan membaca, menulis dan diskusi; dan (3) personal involvement meliputi: menghadiri pertemuan dengan guru/sekolah dan kegiatan, menjadi relawan di sekolah, bercita-cita tinggi tetapi realistis terhadap kemampuan anak

\section{Aktualisasi Diri}

Sardiman (1988: 80); Goble (dalam Burleson, 2005: 439); Eva Latipah (2012: 166) menyatakan aktualisasi diri merupakan kebutuhan psikologis agar keberadaannya diakui 
sesuai dengan dirinya sendiri atau menjadi diri sendiri. Oleh karena itu, orang yang beraktualisasi diri senantiasa menumbuhkan, mengembangkan dan menggunakan kemampuan terbaiknya untuk menjadi diri sendiri. Maslow (1970: 63-64) menyatakan, hal penting dalam pendidikan adalah memproduksi pengalaman belajar, ekspresi diri dan merangsang keingintahuan. Karena ketiga hal ini menunjukkan kemampuan yang diinginkan (need for competence). Need for competence akan semakin meningkat bila, siswa merasakan kegagalan dalam belajar, mendapatkan penghargaan/hukuman, menghadapi permasalahan, melakukan percobaan yang pada akhirnya, akan menguatkan kepribadian dan aktualisasi diri siswa. Berdasarkan uraian di atas dapat pula disimpulkan bahwa aktualisasi diri merupakan sebuah proses.

Menguatkan pendapat Maslow, Brophy (2004: 311) menyatakan, alasan utama keterlibatan siswa dalam pembelajaran adalah pemberdayaan (empowerment) dan aktualisasi diri (self-actualization). Pemberdayaan dan pengembangan aktualisasi diri merupakan hal yang harus dikembangkan dalam pelaksanaan pembelajaran. Pendapat Brophy ini melengkapi pendapat Maslow karena tidak ada pemberdayaan jika tidak ada aktivitas yang akan memberikan tambahan pengalaman belajar, di mana aktivitas ini dapat berhasil atau gagal.

Maslow (Feist \& Feist, 2010: 343); Furst and Steele (Brophy, 2004: 312) menyatakan dengan aktualisasi diri maka manusia menjadi lebih berharga karena menjunjung tinggi nilainilai kemanusiaan. Berdasarkan uraian di atas disimpulkan bahwa aktualisasi diri seseorang dilatarbelakangi untuk mencapai nilai-nilai kehidupan, dengan ciri-ciri: (1) peduli; (2) menjaga/merawat kemampuan diri; (3) pencapaian prestasi; (4) memahami orang lain; (5) mencapai pengakuan/penghargaan diri; (6) mengamati realita secara efisien; dan (7) spontanitas, kesederhanaan dan kewajaran.

\section{Motivasi Berprestasi}

McClelland (Eva Latipah, 2012: 169) menyatakan terdapat tiga kebutuhan yaitu need for achievement, need for affiliation dan need for power. Namun, dalam pembelajaran need for achievement mendapat penekanan yang lebih besar. Nicholls (Wigfield \& Eccles, 2002: 1); Eccles, Wigfield, \& Schiefele
(Wigfield \& Eccles, 2002: 1) menyatakan bahwa motivasi berprestasi berdasarkan pada keinginan individu untuk memiliki kompetensi tertentu secara persisten, bersemangat dan menunjukkan kualitas perkerjaan yang baik. Sehingga disimpulkan motivasi berprestasi merupakan sikap seseorang dalam melakukan pekerjaan/tugas dengan ciri berprestasi melaksanakan tugas walaupun sulit, tekun (persistence) dan bersungguh-sungguh dalam melaksanakan tugas, serta kualitas tugas yang baik dinilai dari waktu. Pengertian ini, secara intrinsik mengandung dua unsur, yaitu kemampuan kognitif dan emosi. Untuk itu, dapat pula disimpulkan bahwa motivasi berprestasi merupakan gabungan antara kemampuan kognitif dan emosi.

Pendapat lain disampaikan oleh Hewitt (2008: 32-33) yang membagi macam motivasi berprestasi siswa dalam belajar dalam dua kelompok yaitu orientasi kepada hasil (performance oriented learning) dan orientasi pada penguasaan (mastery orientated learning). Dweck (dalam Alderman, 2004: 87) yang menyatakan bahwa ada dua perbedaan dalam motivasi berprestasi yaitu seeking to prove one's competence versus seeking to improve one's competence. Seeking to prove one's competence identik dengan performance oriented learning sedangkan seeking to improve one's competence identik dengan mastery orientated learning.

Pendapat berbeda disampaikan oleh Eccles and Wigfield (McInerney, 2000: 24) menyatakan bahwa hasil pencapaian seseorang dipengaruhi oleh: (1) attainment value, i.e. the importance of doing well on the task; (2) intrinsic value, i.e. the inherent, immediate enjoyment one derives from the task; dan (3) utility value, i.e. the perceived importance of the activity to a future goal such as advancing one's career prospects. Atkinson (McInerney, 2000: 23) menyatakan bahwa setiap orang mempunyai kecenderungan untuk mencapai keberhasilan dan menolak kegagalan.

Berdasarkan berbagai teori di atas dapat diambil kesimpulan bahwa, motivasi berprestasi adalah keinginan dari dalam tiap individu untuk mencapai kesuksesan yang didasarkan pada: (1) keinginan untuk sukses; (2) menolak kegagalan; (3) perwujudan kualitas pribadi yang diinginkan; (4) pencapaian tujuan; dan (5) bagian dari kesenangan. 


\section{Prestasi Belajar}

\section{Pengertian Prestasi Belajar}

Proses belajar mengajar diharapkan menghasilkan berbagai perubahan, di antaranya adalah perubahan pengetahuan yang tampak pada prestasi belajar yang dihasilkan oleh siswa, terhadap pertanyaan/persoalan/tugas yang diberikan guru. Winkel (1983: 102). Good ( Wiyono, 2003: 29) menyatakan bahwa prestasi belajar merupakan pengetahuan yang diperoleh atau keterampilan yang dikembangkan dalam pelajaran di sekolah, yang biasanya ditunjukkan dengan skor atau nilai. Sehingga disimpulkan prestasi belajar sebagai hasil kegiatan belajar yang dinyatakan dalam bentuk angka yang mencerminkan hasil yang sudah dicapai oleh setiap siswa yang dapat diukur dari tes atau hasil ujian siswa. Di samping itu, dari pernyataan di atas dapat disimpulkan bahwa prestasi belajar identik penilaian pembelajaran. Jika nilainya baik maka, dapat dikatakan bahwa prestasi belajarnya baik. Prestasi belajar dapat diketahui seorang guru dengan cara melakukan tes prestasi pada periode tertentu (Sukardi, 2010: 139).

\section{Penilaian Hasil Belajar}

Lambert and Lines (dalam Butt, 2010: 3) menyatakan bahwa penilaian merupakan proses mengumpulkan, menginterpretasikan, merekam dan menggunakan informasi tentang tangggapan/jawaban siswa terhadap tugas yang diberikan guru (educational task). Black (1998: 5) menyatakan bahwa penilian merupakan istilah umum yang mencakup semua metode yang digunakan untuk menilai prestasi (performance) siswa secara individu atau sekelompok siswa. Berdasarkan kedua pengertian di atas, pendapat Black lebih sesuai karena, penilaian dapat dilakukan secara lisan/wawancara di dalam kelas, pemberian tugas (teori/ praktek), ulangan harian, ujian akhir dan lainlain. Metode penilaian banyak macamnya. Black (1998: 81-88) menyebutkan beberapa metode yang sering digunakan yaitu: fixed response, closes response, essay type, performance assessment.

\section{METODE PENELITIAN}

\section{Jenis Penelitian}

Pedekatan penelitian yang digunakan adalah pendekatan penelitian kuantitatif dengan rancangan ex post facto.

\section{Waktu dan Tempat Penelitian}

Tempat penelitian ini adalah di Kabupaten Gunungkidul. Penelitian dilakukan pada bulan Januari - Maret 2013.

\section{Populasi dan Sampel}

Populasi penelitian ini adalah siswa kelas XII jurusan Teknik Kendaraan Ringan di SMK Negeri se-Kabupaten Gunungkidul sebanyak 8 sekolah sebanyak 535 siswa, dengan jumlah sampel 237 siswa. Teknik penarikan sampel penelitian ini adalah Proportional Random Sampling. Dalam menentukan jumlah sampel menggunakan tabel KrejcieMorgan dengan tingkat kesalahan 5\%.

\section{Prosedur}

Data penelitian dikumpulkan dengan angket dan tes prestasi. Untuk memastikan kelayakan instrumen dalam penelitian ini dilakukan validasi isi oleh expert judgment (ahli). Validasi konstruk angket digunakan analisis faktor dan untuk tes prestasi menggunakan analisis butir. Uji reliabilitas instrumen digunakan koefisien alpha.

\section{Data, Instrumen dan Teknik Penggumpulan Data}

Data penelitian merupakan hasil angket dan tes prestasi. Angket digunakan untuk mengetahui kinerja mengajar guru, keterlibatan orang tua, aktualisasi diri dan motivasi berprestasi. Sedangkan tes prestasi digunakan untuk mengukur prestasi siswa.

\section{Teknik Analisis Data}

Untuk mengetahui gambaran tiap variabel digunakan analisis deskriptif, sedangkan untuk menguji pengaruh digunakan analisis regresi, dengan terlebih dahulu dilakukan uji persyaratan analisis yang meliputi normalitas, linieritas, multikolinieritas, dan heteroskedasitas.

\section{HASIL PENELITIAN DAN PEMBAHASAN}

Hasil analisis deskriptif menunjukkan bahwa kinerja mengajar guru berdasarkan penilaian siswa tergolong dalam kategori tinggi dengan persentase mencapai $67,51 \%$. Selaras dengan dimensi mengajar guru yaitu me- 
rencanakan, melaksanakan dan menilai pembelajaran secara umum berada dalam kategori tinggi. Namun demikian pencapaian skor $67,51 \%$ berada dalam level bawah kategori tinggi dan cukup jauh dari skor maksimal $(100 \%)$. Sehingga kinerja mengajar guru belum mencapai hasil optimal dan masih diperlukan upaya perbaikan. Hal ini selaras dengan kecenderungan skor yang menunjukkan bahwa 19,83\% responden menyatakan bahwa kinerja mengajar guru masih dalam kategori cukup. Oleh karena itu sangat beralasan jika berbagai upaya peningkatan kinerja mengajar guru harus selaku dilakukan.

Jika dilihat dari tiap aspek kinerja mengajar guru, diperoleh bahwa nilai rata-rata perencanaan pembelajaran sebesar 2,71 , melaksanakan pembelajaran sebesar 3,05 dan penilaian pembelajaran sebesar 3 dari nilai rata-rata optimal sebesar 4. Berdasarkan nilai rata-rata di atas nilai perencanaan pembelajaran merupakan nilai terendah. Hal ini menunjukkan bahwa perencanaan pembelajaran merupakan aspek terlemah kinerja mengajar guru yang meliputi pemberian prasarat pembelajaran, perencanaan pelaksanaan pembelajaran dan perencanaan penilai pembelajaran. Berdasarkan Slavin (2011: 277) pembelajaran yang efektif dalam perencanaan meliputi tiga hal yaitu menentukan tujuan pembelajaran, membahas prasarat dan perencaan pemberian materi baru pembelajaran yang mengarah pada tujuan pembelajaran. Perencaan pembelajaran yang baik akan berdampak pada aspek yang lain. Dengan kata lain jika perencanaan pembelajaran baik maka memungkinkan aspek kinerja yang lain akan baik dan sebaliknya. Oleh karena itu aspek perencanaan pembelajaran harus mendapat perhatian lebih dibandingkan dengan dua aspek lainya.

Hasil analisis deskriptif variabel keterlibatan orang tua menunjukkan bahwa berdasarkan penilaian siswa tergolong dalam kategori tinggi dengan persentase mencapai $52,74 \%$. Selaras dengan dimensi keterlibatan orang tua yaitu keterlibatan perilaku, keterlibatan intelektual, dan keterlibatan personal dalam kategori tinggi. Namun demikian pencapaian skor $52,74 \%$ berada dalam level bawah kategori tinggi dan cukup jauh dari skor maksimal (100\%). Sehingga keterlibatan orang tua belum optimal dan masih diperlukan upaya perbaikan. Hal ini selaras dengan ke- cenderungan skor yang menunjukkan bahwa $44,30 \%$ responden menyatakan bahwa keterlibatan orang tua masih dalam kategori cukup. Oleh karena itu sangat beralasan jika berbagai upaya peningkatan keterlibatan orang tua harus selaku dilakukan.

Jika dilihat dari tiap aspek keterlibatan orang tua, diperoleh bahwa nilai rata-rata keterlibatan perilaku sebesar 2,30, keterlibatan intelektual sebesar 2,2 dan keterlibatan personal sebesar 3,2 dari nilai rata-rata optimal sebesar 4. Berdasarkan nilai rata-rata di atas nilai keterlibatan perilaku dan keterlibatan intelektual memiliki nilai rendah. Hal ini menunjukkan bahwa keterlibatan intelektual dan keterlibatan perilaku merupakan aspek yang lemah pada varibel keterlibatan orang tua. Aspek keterlibatan perilaku meliputi perasaan disayangi, keteguhan dan sikap toleran, sedangkan keterlibatan orang tua meliputi menstimulus kecerdasan anak, membantu tugas anak, memantau perkembangan akademik anak, memberi contoh dalam belajar dan mendorong kebiasaan menulis, membaca dan diskusi. Hornby (2000: 50) menyatakan bahwa jika orang tua memiliki kemampuan berbahasa yang baik akan membantu anaknya dalam hal kemampuan membaca. Pernyataan tersebut menunjukkan bahwa kebiasaan orang tua di rumah dalam hal ini membaca dan berbicara dengan baik akan sangat berpengaruh pada kemampuan anak. Sekolah mempunyai peran signifikan untuk mengatasi hal ini, karena rendahnya keterlibatan orang tua bukannya mereka tidak ingin tetapi karena mereka tidak mengetahui keterlibatan yang diinginkan anak.

Hasil analisis deskriptif variabel aktualisasi diri tergolong dalam kategori tinggi dengan persentase mencapai $61,60 \%$. Selaras dengan dimensi aktualisasi diri yaitu peduli, merawat kemampuan diri, pencapaian prestasi, memahami orang lain, mencapai pengakuan dan penghargaan diri, mengamati realitas secara efisien, spontanitas, kesederhanaan dan kewajaran dalam kategori tinggi. Namun demikian pencapaian skor $61,60 \%$ berada dalam level bawah kategori tinggi dan cukup jauh dari skor maksimal (100\%). Sehingga aktualisasi diri belum optimal dan masih diperlukan upaya perbaikan. Hal ini selaras dengan kecenderungan skor yang menunjukkan bahwa $22,36 \%$ responden menyatakan bahwa aktualisasi diri masih dalam 
kategori cukup. Oleh karena itu sangat beralasan jika berbagai upaya peningkatan aktualisasi diri harus selaku dilakukan.

Jika dilihat dari tiap aspek aktualisasi diri, diperoleh bahwa nilai rata-rata sikap peduli sebesar 3,12, merawat kemampuan diri sebesar 3,3, pencapaian prestasi sebesar 3, memahami orang lain 3,48 , mencapai pengakuan dan penghargaan diri sebesar 3, mengamati realitas secara efisien sebesar 3 dan spontanitas, kesederhanaan dan kewajaran sebesar 3, dari nilai rata-rata optimal sebesar 4. Berdasarkan nilai rata-rata di atas semua aspek aktualisasi diri memiliki nilai yang tinggi.

Hasil analisis deskriptif variabel motivasi berprestasi tergolong dalam kategori tinggi dengan persentase mencapai $62,03 \%$. Namun demikian pencapaian skor $61,60 \%$ berada dalam level bawah kategori tinggi dan cukup jauh dari skor maksimal (100\%). Sehingga motivasi berprestasi belum optimal dan masih diperlukan upaya peningkatan. Hal ini selaras dengan kecenderungan skor yang menunjukkan bahwa $29,96 \%$ responden menyatakan bahwa motivasi berprestasi masih dalam kategori cukup. Oleh karena itu sangat beralasan jika berbagai upaya peningkatan motivasi berprestasi harus selaku dilakukan.

Jika dilihat dari tiap aspek motivasi berprestasi, diperoleh bahwa nilai rata-rata keinginan untuk sukses sebesar 2,92, menolak kegagalan 3,11, perwujudan kualitas pribadi yang diinginkan sebesar 3,13 , pencapaian tujuan yaitu prestasi belajar sebesar 3,01 dan bagian dari kesenangan sebesar 3,08 dari nilai rata-rata optimal sebesar 4. Kelima aspek tersebut merupakan bagian dari dua tujuan belajar yaitu penguasaan materi (mastery orientated learning) dan mencapai nilai pada tiap tugas (performance oriented learning). Ames dan Archer (1988: 264) menyatakan bahwa siswa yang bertujuan penguasaan materi lebih suka pada tugas yang menantang, lebih nyaman di kelas, dan lebih yakin akan sukses.

Hasil analisis deskriptif variabel prestasi belajar tergolong dalam kategori cukup dengan persentase mencapai $47,68 \%$. Namun demikian pencapaian skor $47,68 \%$ berada dalam level bawah kategori tinggi dan cukup jauh dari skor maksimal 100. Oleh karena itu sangat beralasan jika berbagai upaya peningkatan motivasi berprestasi harus selalu dilaku- kan. Beberapa di antaranya adalah kinerja mengajar guru, keterlibatan orang tua, aktualisasi diri dan motivasi berprestasi. Dari berbagai teori tentang kinerja mengajar guru, guru harus mampu mengelola dan mempertahankan motivasi siswa dalam belajar dengan menciptakan lingkungan belajar yang baik. Oleh karena itu kemampuan guru dalam pengelolaan kelas (pertemuan langsung) harus senantiasa ditingkatkan.

Berdasarkan hasil uji hipotesis diketahui bahwa terdapat pengaruh kinerja mengajar guru, keterlibatan orang tua, aktualisasi diri dan motivasi berprestasi terhadap prestasi belajar masing-masing sebesar 0,$145 ; 0,128$; 0,108 dan 0,098. Kontribusi kinerja mengajar guru, keterlibatan orang tua, aktualisasi diri dan motivasi berprestasi terhadap prestasi belajar sebesar $9,0 \%$.

Berdasarkan hasil penelitian terbukti bahwa kinerja mengajar guru berpengaruh terhadap motivasi berprestasi siswa. Hal ini senada dengan yang dinyatakan Slavin (2011: 99) bahwa tugas pendidik bukanlah meningkatkan motivasi pada dirinya, melainkan menemukan, menyalakan dan mempertahankan motivasi siswa untuk mempelajari pengetahuan dan kemampuan yang diperlukan demi keberhasilan di sekolah dan dalam kehidupan, dan untuk terlibat dalam kegiatan yang menghasilkan pembelajaran ini. Pendapat Slavin dikuatkan oleh penelitan yang dilakukan oleh Wesson (2011: 28) menemukan, sikap guru berpengaruh pada perhatian dan antusiasme siswa adalah kejelasan suara, kontak mata, gerak tubuh dan ekspresi wajah. Guru yang berkeliling ruangan ketika mengajar, secara tidak langsung membuat siswa merasa diperhatikan, sehingga memiliki konsentrasi belajar yang lebih. Hal ini akan semakian baik, jika guru memperhatikan perbedaan tiap individu siswa, karena tidak semua siswa dalam suatu kelas memiliki kemampuan yang sama dalam pembelajaran. Dengan berkeliling dikelas, guru dapat mengetahui siswa yang membutuhkan bantuan dalam pembelajaran. Tingkat sensitivitas guru dalam membantu siswa yang kurang mampu akan berpengaruh pada motivasi dan mendorong siswa untuk menunjukkan kemampuan terbaiknya (Hardre, Sullivan, \& Crowson, 2009: 14).

Tugas yang diberikan guru dapat meningkatkan motivasi berprestasi siswa. Siswa yang memiliki motivasi berprestasi tinggi 
akan merasa tertantang dengan tugas yang sulit. Oleh karena itu, guru dapat memberikan tugas yang berbeda tingkat kesulitan dalam pembelajaran, sesuai dengan kemampuan siswa. Hal ini sesuai dengan Leighbody \& Kidd (1966: 2) menyatakan tentang prinsip-prinsip pembelajaran, salah satu diantaranya adalah kesuksesan belajar akan membangkitkan rasa keingintahuan siswa. Oleh karena itu guru harus merencanakan pembelajaran dengan baik. Salah satu yang harus dilakukan guru ketika akan mengajarkan sebuah kompetensi, adalah memecah kompetensi yang akan diajarkan menjadi bagian-bagian yang lebih kecil, sehingga dalam pelaksanaan pembelajaran lebih mudah diaplikasikan dan siswa lebih mudah memahami.

Pada saat merencanakan pembelajaran, berdasarkan teori perkembangan kognitif yang disampaikan oleh Vygostky, diaplikasikan dengan menyusun rencana pembelajaran kooperatif di antara kelompok-kelompok siswa yang mempunyai tingkat kemampuan yang berbeda. Sehingga sistem pembelajaran teman sebaya menjadi penting untuk dilakukan. Selain itu dalam pembelajaran hendakmya dilakukan sistem pentanggaan, dengan siswa memikul tanggung jawab atas pembelajaran mereka sendiri. Dalam pelaksanaan pembelajaran, seorang guru membentuk kelompokkelompok kecil siswa untuk mengajukan pertanyaan tentang bahan ajar yang telah dipelajari dan secara bertahap mengalihkan tanggung jawab untuk memimpin diskusi kepada siswa (Slavin, 2011: 61).

Aktivitas guru selama melaksanakan pembelajaran langsung di dalam kelas, hendaknya mendapat perhatian manajemen sekolah. Karena motivasi belajar siswa dapat tumbuh apabila mendapat pengaruh faktor eksternal, salah satunya adalah kinerja mengajar guru. Jika guru dalam mengajar menarik, menggunakan bahasa yang baik, mempunyai hubungan emosional yang baik akan berdampak pada lingkungan kelas yang baik, sehingga membantu proses belajar mengajar. Hal ini senada dengan hasil penelitian yang dilakukan oleh Hardre, Sullivan, \& Crowson (2009: 14) menemukan bahwa motivasi belajar sangat dipengaruhi oleh lingkungan belajar yang dibentuk oleh guru.

Hallinan (2008: 273) menyatakan bahwa guru dalam proses pembelajaran memiliki dua tugas yaitu peduli dengan siswa dan melatih/membimbing siswa. Pendapat ini berdasarkan pada teori psikologi yang menyatakan bahwa interaksi positif yang dilakukan terhadap seseorang atau lebih dalam waktu yang lama akan berpengaruh terhadap perkembangan sosial dan emosional seseorang (socioemotional development). Jika siswa mendapat perlakukan negative dari guru, maka sikap negative pula yang akan berkembang, begitu pula sebaliknya.

Sikap positif guru berupa mau mendengar pendapat siswa, mendorong kemajuan siswa dan menciptakan lingkungan belajar yang baik. Brophy (Hallinan, 2008: 273) menyatakan, memberikan penghargaan terhadap siswa akan berdampak efektif terhadap motivasi, kepercayaan diri, dan sikap positif siswa disekolah. Dengan motivasi yang tinggi, kepercayaan diri akan berhasil dalam pendidikan dan senantiasa mengembangkan sikap postitif, maka prestasi belajar yang baik sangat mungkin untuk dicapai.

Keterlibatan orang tua dalam pendidikan anak berpengaruh terhadap motivasi berprestasi. Hal ini menunjukkan bahwa segala jenis keterlibatan orang tua dalam pendidikan yang menyangkut keterlibatan secara personal, keterlibatan pedagogik, dan komunikasi dengan sekolah sangat mempengaruhi motivasi siswa. Pendidikan orang tua dan banyaknya waktu yang dialokasikan untuk anak merupakan hal penting dalam meningkatkan keterlibatan orang tua (Houtenville \& Conway, 2008: 450). Pendapat ini mengindikasikan bahwa kedekatan dan sikap terbuka orang tua terhadap anak merupakan hal yang harus diperhatikan oleh setiap orang tua.

Dalam belajar siswa akan mendapati dua kondisi yaitu sukses/memahami materi pembelajaran atau gagal memahami materi pembelajaran. Motivasi berprestasi berperan pada keinginan untuk dapat memahami materi pembelajaran, walaupun sulit. Hasil kegiatan pembelajaran, terutama yang gagal, tetap bermanfaat karena meningkatkan kepahaman siswa terhadap materi pembelajaran. Hal ini sangat tampak pada pembelajaran praktek. Pada saat siswa gagal menyelesaikan sebuah tugas praktek, terjadi proses penambahan jam terbang terhadap pembelajaran. Penelitian Turner, Chandler, \& Heffer (2009: 343); Grolnick \& Slowiaczek (Kathryn \& Wentzel, 2009: 282) menemukan tipe keterlibatan orang tua yang mendukung dan hangat sangat 
berpengaruh kepada prestasi siswa. Hal ini terjadi karena siswa yang senantiasa mendapat dukungan orang tua, mempunyai kepercayaan diri dan keinginan maju yang tinggi.

Slavin (2011: 135) menyatakan peran sekolah untuk meningkatkan keterlibatan orang tua diantaranya: (1) kunjungan keluarga pada awal semester untuk mengetahui dukungan keluarga, kondisi psikologi dan kecerdasan siswa; (2) menyampaikan berita berkala yang sering kepada orang tua, untuk mengetahui tingkat keberhasilan pembelajaran; (3) lakukan lokakarya orang tua, dengan mengundang orang tua ke sekolah sehingga guru/ sekolah dapat menjelaskan program pembelajaran dan harapan guru/sekolah dapat membantu orang tua memahami bagaimana cara mendukung pembelajaran anak; (4) sampaikan berita positif ke rumah melalui telefon, sehingga menghasilkan dukungan positif dan meningkatkan kemungkinan perilaku tersebut berlanjut; (5) ajak anggota keluarga menjadi sukarelawan; dan (6) jadikan orang tua sebagai mitra.

Aktualisasi diri sangat berpengaruh terhadap motivasi dan prestasi belajar. Aktualisasi diri memiliki dua dimensi yaitu personal dan sosial. Dimensi personal di antaranya dengan bersikap jujur dan bertanggung jawab, sedangkan dimensi sosial di antaranya adalah peduli dan senang membantu orang lain. Seseorang yang beraktualisasi diri memiliki kepahaman yang baik tentang dirinya dan orang lain. Ia mudah memberikan pertolongan kepada orang lain yang membutuhkan. Jika hal ini diterapkan pada proses pembelajaran, siswa yang beraktualisasi diri tidak segan membantu siswa lain yang mengalami kesulitan belajar, dan sebaliknya. Dengan membantu siswa yang mengalami kesulitan belajar, berarti menambah jam belajar dan akan meningkatkan kepahaman, sehingga akan berpengaruh terhadap prestasi belajar. Dengan kata lain orang yang beraktualisasi diri memiliki tingkat kecerdasan emosional (EQ) yang baik.

Aktualisasi diri mendorong seseorang untuk berbuat lebih baik dalam melaksanakan tugasnya. Orang yang beraktualisasi diri, berpengaruh terhadap diri sendiri dan orang lain. Pengaruh aktualisasi diri terhadap diri sendiri, terkait dengan pengembangan kemampuan personal, yang ditandai dengan sikap merasa ingin tahu sehingga memiliki kemauan untuk belajar yang lebih dan selalu jujur terhadap diri sendiri. Sedangkan pengaruh terhadap orang lain menyebabkan orang yang beraktualisasi diri disenangi oleh banyak orang. Sebagaimana yang disampaikan oleh O'Connor \& Yballe (2007: 752-753), yang menyatakan bahwa aktualisasi diri berpengaruh pada aspek fisik, sosial, individu dan spiritual. Khusus untuk siswa aktualisasi diri berdampak pada motivasi, kerja keras dan berpikiran positif.

Keterlibatan orang tua dalam pendidikan anak sangat berpengaruh terhadap prestasi belajar. Sebagaimana kita ketahui keterlibatan orang tua dalam pendidikan anak, terbagi menjadi dua kelompok, yaitu keterlibatan orang tua dalam keluarga dan keterlibatan orang tua terhadap sekolah. Penelitian Altschul (2011: 169) menemukan bahwa keterlibatan orang tua dalam keluarga memiliki pengaruh dominan terhadap prestasi dibandingkan dengan keterlibatan orang tua dalam pendidikan terhadap sekolah.

Interaksi di dalam keluarga ditandai dengan komunikasi yang baik. Komunikasi yang di maksud adalah komunikai dua arah. Sehingga siswa dan orang tua saling mengetahui keinginan/harapan masing-masing. Komunikasi menyangkut aspek fisik dan mental. Aspek fisik berarti bertemu secara fisik antara anak dan orang tua, sedangkan aspek mental meliputi merasa diperhatikan, disayangi, peduli dan lain-lain. Penelitian Ilyas (2003: 87) menemukan terdapat pengaruh positif komunikasi antara orang tua dengan siswa terhadap prestasi belajar. Hal ini berarti semakin baik/ tinggi intensitas komunikasi antara orang tua dan anak, maka akan semakin baik prestasi belajar anak dan sebaliknya.

Siswa yang memiliki motivasi berprestasi yang tinggi akan berpeluang besar mencapai kesuksesan belajar (prestasi). Eccles (Fortune, Lee, \& Cavazoz, 2005: 115) menyatakan motivasi berprestasi ditandai dengan sikap semangat menyelesaikan tugas yang diberikan, pantang menyerah jika menemukan tugas yang sulit, dan keyakinan dapat menyelesaikan tugas dengan baik. Siswa memiliki dua tujuan dalam pembelajaran yaitu menguasai materi (mastery goal) dan nilai (performance goal). Namun siswa yang memiliki motivasi berprestasi tinggi, memiliki tujuan untuk menguasai materi. Dengan keinginan untuk menguasai materi, maka 
akan siswa akan memiliki fokus/target dalam belajar dan tidak mudah menyerah.

\section{SIMPULAN DAN SARAN}

Berdasarkan hasil analisis data dan pembahasan, dapat ditarik kesimpulan bahwa terdapat pengaruh kinerja mengajar guru, keterlibatan orang tua, aktualisasi diri dan motivasi berprestasi terhadap prestasi belajar masing-masing sebesar 0,$145 ; 0,128 ; 0,108$ dan 0,098.

Berdasarkan kesimpulan di atas, maka disampikan beberapa saran yaitu :

1. Kinerja guru merupakan faktor dominan yang mempengaruhi prestasi belajar siswa. Oleh karena itu kinerja guru harus senantiasa ditingkatkan dengan cara melakukan supervisi kinerja mengajar guru. Supervisi kinerja mengajar guru terdiri dari: (1) perencanaan pembelajaran dengan cara mengecek kelengkapan administrasi pembelajaran terutama kesiapan silabus dan rencana pelaksanaan pembelajaran (RPP); (2) pelaksanaan pembelajaran dengan menilai guru dalam mengajar di dalam kelas/bengkel dengan cara membandingkan langkah-langkah pembelajaran yang telah direncakanan dalam RPP atau dengan standar yang telah ditetapkan pemerintah/sekolah dengan kenyataan yang dilakukan oleh guru; (3) penilaian pembelajaran dengan cara melakukan evaluasi terhadap hasil penilaian pembelajaran yang dilakukan guru, apakah telah memenuhi ketuntasan minimal atau tidak, serta tingkat keberhasilan pembelajaran yang dilakukan guru dalam kelas tertentu.

2. Keterlibatan orang tua memiliki pengaruh yang signifikan terhadap prestasi belajar siswa. Oleh karena itu hendaknya orang tua harus meningkatkan segala bentuk keterlibatan dalam pendidikan anaknya. Hal ini dapat dilakukan dengan membentuk kondisi keluarga yang baik, membuat peraturan keluarga, pembagian peran/ tugas dalam keluarga, memenuhi buku pegangan yang dibutuhkan anak, memantau perkembangan pembelajaran anak, dan terlibat aktif dalam pertemuan dengan sekolah.

3. Aktualisasi diri memiliki pengaruh signifikan terhadap prestasi belajar. Oleh karena itu hendaknya orang tua mendorong anaknya untuk beraktualisasi di lingkungan sekolah, terlebih lagi dalam masyarakat. Karena dengan cara seperti itu, akan terlatih ketrampilan siswa dalam mengungkapkan pendapat di depan umum/komunikasi dengan banyak orang. Selain itu sekolah memfasilitasi aktualisasi diri siswa dengan cara mengaktifkan organisasi siswa dan menyediakan anggaran yang cukup.

4. Motivasi berprestasi berpengaruh signifikan terhadap prestasi belajar. Oleh karena itu hendaknya sekolah mengadakan kegiatan yang dapat meningkatkan motivas belajar siswa. Salah satu contoh adalah mengundang siswa yang telah sukses/bekerja sebagai guru tamu, untuk menceritakan realita industry/kebutuhan industry. Selain itu dialkukan kegiatan kunjungan industri dengan berkunjung pada industri yang sesuai dengan kompetensi yang ada di sekolah.

\section{DAFTAR PUSTAKA}

Alderman, M.K (2004). Motivation for Achievement:possibilities for teaching and learning $\left(2^{\text {nd }} e d\right)$. New Jersey : Laurence Erlbaum Associates.

Altschul, I. (2011). Parental Involvement and Academic Achievement of Mexican American Youths: What Kinds of Involvement in Youths' Education Matter Most?. Social Work Research, $35,3,159-170$.

Ames, C., \& Archer, J. (1988). Achievement Goals in the Classroom:Students' Learning Strategies and Motivation Prosesses. Journal of Educational Psychology ,80, 264.

Black, P. J. (1998).. London: Falmer Testing: Friend or Foe? The Theory and Practice of Assessment and Testing. Falmer Press.

Briggs, A. R., \& Sommefeldt, D. (2002). Managing Effective Learning and Teaching. London: SAGE Publication Company. 
Brophy, J.(2004). Motivating Student to Learn $\left(2^{\text {nd }} e d\right)$. New Jersey: Laurence Earbaum.

Burleson, W.(2005). Developing Creativity, Motivation and Self Actualization with Learning System. International Journal of Human-Computer Studies, 439.

Butt, G. (2010). Making Assessment Matter. New York: Continum International Publishing Group.

Conway, K. S., \& Houtenville, A. J. (2008). Parental Effort, School Resources, and Student Achievement. The Journal of Human Resources. XLIII. 2, 438-453.

Cooper, P., \& McIntyre, D. (1996). Effective Teaching and Learning Teachers' and Student Perspective. Oxfordshire: Marston Lindsay Ross International Ltd.

Desforges, C., \& Abouchaar, A. (2003). The Impact of Parental Involvement, Parental Support and Family Education on Pupil Achievement and Adjustment: A Literature Review. Queen Printer.

Farooq, M. S., Chaudhry, A. H., Shafiq, M., et al. (2011) Factor Effecting Student's Quality of Academic Performance: a Case of Secondary School Level. Journal of Quality and Technology Management, Vol. VII, Issue II, 1-14.

Feist, J., \& Feist, G. (2010). Teori Kepribadian $\left(7^{\text {th }} e d\right)$. Jakarta. Salemba. Humanika.

Glickman, P. D. (2002). Leadership for Learning How To Help Techer Succeed. Alexandria: ASDC.

Hadre, P. L., Sullivan, D. W., \& Crowson, H.M. (2009). Student Characteristics and Motivation in Rural High School. Journal of Research in Rural Education, 4(16), 1-19.

Hallinan, M, T. (2008). Teacher Influences on Students' Attachment to School. Sociology of Education, 81, 3, 271-283.
Hamalik, O. (2004). Psikologi Belajar dan Mengajar. Bandung: Sinar Baru Algesindo.

Hewitt, D. (2008). Understanding Effective Learning. Berkshire: Open University Press.

Hornby, G. (2000). Improving Parental Invovement. New York: Continum.

Ilyas (2004). Pengaruh Komunikasi Orang Tua Terhadap Prestasi Belajar Siswa Pada MTsN Model Makassar (Suatu Studi Komunikasi Pendidikan). Tesis Magister. Tidak diterbitkan, Universitas Hasanuddin, Makassar.

Khan, A., Shah, I. M., Khan, S., et al. (2012). Teacher Stress, Performance \& Resources The Moderating Effect of Resources on Stress and Performnace. International Review of Social Science and Humanities, Vol.2, No. 2, 21-29.

Konstantopoulos, S. (2006). Trends of School Effect on Student Achievement: Evidence from NLS: 72, HSB: 82, and NELS: 92. Teachers College Record, Vol. 108, No. 12, 2550-2581.

Kyriacou, C. (2009). Effective Teching in School Theory and Practice $\left(3^{\text {rd }}\right.$ ed). Cheltelham: Nelson Thornes Ltd.

Latipah, E. (2012). Pengantar Psikologi Pendidikan. Yogyakarta: Pustaka Insan Madani.

Leighbody, \& Kidd. (1968). Methode of Teaching Shop and Technical Subject. New York : Delmar Publisher.

Marzano, R. J. (2007). The Art and Science of Teaching. Alexandria: ASDC.

Maslow, A. H. (1970). Motivation and Personality, Harper \& Row.

McInerney, D. M. (2000). Helping Kids to Achieve Their Best: Understanding and Using Motivation in the Classroom. Sydney: Allen \& Unwin. 
Middlewood, D., \& Cardno, C. (2001). Managing Teacher Appraisal and Performance. London. Routhledge Falmer.

Mushtaq, I., \& Khan, S. N. (2012). Factors Effecting Students' Academic Performance. Global Journal of Management and Business Research, Vol. 12, Issue 9, Version 1.0, 22.

O'Connor, D., \& Yballe, L. (2007). Maslow Revisited: Constructing Road Map of Human Nature. Journal of Management Education, 738-756.

Purwanto, Ngalim. (2006). Psikologi Pendidikan. Bandung: Remaja Rosdakarya.

Sardiman. (1988). Interaksi dan Motivasi Belajar Mengajar. Jakarta: Rajawali.

Slameto. (1991). Belajar dan Faktor-Faktor yangMempengaruhinya. Salatiga. Bumi Aksara.

Slavin, R. E. (2011). Psikologi Pendidikan Teori dan Praktek $\left(9^{\text {th }}\right.$ ed) jilid 1. Jakarta. Indeks.

Slavin, R. E. (2011). Psikologi Pendidikan Teori dan Praktek $\left(9^{\text {th }}\right.$ ed) jilid 2. Jakarta. Indeks.

Steinberg, L. (1996). Beyond the Classroom : Why School Reform Has Failed and What Parent Need to Do. New York: Simon \& Schuster.

Sukardi. (2010). Metodogi Penelitian Pendidikan kompetensi dan Praktiknya. Jakarta: PT. Bumi Aksara.
Turner, E. A., Chandler, M., \& Heffer, R. W. (2009). The Influence of Parenting Styles, Achievement Motivaton and Self-Efficacy on Academic Performance in College Student. Jounal of College Student Development, Vol. 50, No. 3, 337-346.

Usman, M. U. (2013). Menjadi Guru Profesional $\left(2^{\text {nd }} e d\right)$. Bandung: Remaja Rasdakarya.

Wentzel, K., \& Wigfield, A. (2009). Handbook Motivation at School. New York: Routhledge.

Wesson, R. H. (2011). The Impact of Performnace Skill on Students' Attitude Toward the Learning Experience in Higher Education. Issue in Educational Research, 21 (1), 22-41.

Wigfield, A., \& Eccles, J.S. (2002). Development of Achievement Motivaton. Michigan: Academic Press.

Winkel, W.S. (1983). Psikologi Pendidikan dan Evaluasi Belajar. Jakarta: Gramedia.

Wiyono, B. B. (2003). Hubungan Lingkungan Belajar, Kebiasaan Belajar dan Motivasi Belajar dengan Prestasi Belajar Siswa. Forum Penelitian, Th. 15, No.1, 28-36. 